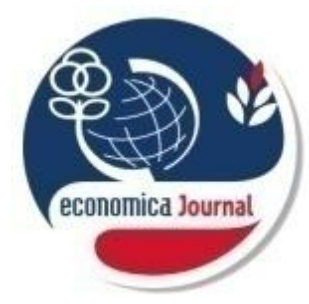

ISSN : $2302-1590$

E-ISSN: $2460-190 \mathrm{X}$

\title{
ECONOMICA
}

\author{
Jurnal Program Studi Pendidikan Ekonomi \\ STKIP PGRI Sumatera Barat Vol.8 No.1 (65-77)
}

\section{RISK PERCEPTION (PERFORMANCE AND PHYSICAL) ON DECISIONS OF USING CONVENTIONAL TRANSPORTATION SERVICES}

\author{
By \\ Siska Lusia Putri ${ }^{1)}$, Lasti Yossi Hastini ${ }^{2)}$ \\ ${ }^{1)}$ Management Study Program, Faculty of Economics and Business, Universitas Dharma Andalas \\ E-mail: siskalusiaputri@unidha.ac.id \\ 2) Management Study Program, Faculty of Economics and Business, Universitas Dharma Andalas \\ E-mail: lasti.yossi@gmail.com \\ Submited: 2019.09.14 Reviewed: 2019.10.14 Accepted:2019.10.29 \\ https://doi.org/10.22202/economica.2019.v8.i1.3591
}

\begin{abstract}
Ojek is one of the conventional transportation that is popular with people in big cities. Eventhough the physical condition of the drivers and the physical condition of the vehicle used is still far below the standard, services consumers still like it. Even sometimes there are drivers who are not polite, do not maintain physical appearance to set a volatile ojek's price. The purpose of this study was to analyze effect of RP-Performance of conventional transportation (ojek); to analyze effect of RP-Physical of conventional transportation (ojek); and to analyze effect of risk perception (RP-Performance and RP-Physical) for taking decision on using service of conventional transportation (ojek). The data were collected from 384 respondents who has ever used conventional transportation for one years by using Quota Sampling method. The result of the study showed that (1) RP-Performance conventional transportation is negative and significant impact for taking decision; (2) RP-Physical conventional transportation is negative and significant impact for taking decision; and (3) Risk perception (RP-Performance and RP-Physical) conventional transportation are stimultaneously have significant for taking decision. The value of adjusted $R$ Square indicators was $25.7 \%$.
\end{abstract}

Jel Classification:

D83; D83; L62

Keywords: RP-Performance; RP-Physical; ojek 


\section{INTRODUCTION}

A person's tendency to rely on instincts that he/she has to ultimately consider whether something will be at risk or not for himself. There are many factors that are considered by a consumer, that are the level of involvement the purchase price of a product/service to the previous experience when buying a product/service (Sumarwan, 2011). Risk perception (risk perception) here produces a moderating effect for each consumer. This is caused by the instincts that exist in every consumer and there is a tendency to avoid an error even if a little. In fact, the higher the risk perception of a product/service, the consumer will find out what information is attached to the product/service, starting from the composition of the product, product quality, authenticity of the product/service to the security of the product/service itself. Then Gunawan, et al (2007) explained that the definition of RP-Performance Risk is the risk associated with the reality of the performance of the product/service purchased whether it is appropriate or not with what was previously imagined (expectations). While RP-Physical Risk is a risk that threatens the physical condition of consumers and security for the purchase of products/services that have been purchased.

Putri, et al. (2013) stated that research on risk perception was generally related to the risk of purchasing products online, adopting new products, and booking airline tickets through the internet. Research on risk perceptions of decisions on using service is rarely examined whether land transportation (public transportation (angkot), taxi, motorcycle taxi (ojek)); sea transportation (ship) and air transportation (airline / aircraft).

Conventional transportation in the form of ojek is quite a lot in number for public transportation in Padang besides public transportation (angkot) and city buses. The existence of ojek is favored by the people in
Padang because it is considered to be more efficient in terms of time because there are not as many as passengers and city buses that sometimes waited for passengers to full. The physical and the appearance of ojek drivers and the vehicles used do not all look good (good looking). However, consumers still choose it because there is no other choice. Compared to public transportation and city buses, ojek is still popular with the people in Padang. Performance Risk and Physical Risk, this is what consumers considered.

Unlike the case with conventional transportation, online transportation such as PT. Gojek Indonesia (Go-Jek) since its inception in 2011, has become an online ojek transportation service provider company. The service facilities provided are also diverse, including Go-ride and Go-car facilities that are used as a service to pick-up and drop passengers, Go-send facility as a goodsdelivery service, Go-food facility as a fooddelivery service and Go-shop facilities as a service shop.

Go-Jek itself began to operate in Padang around mid-2017. The beginning existence of Go-Jek brought pros and cons to the people of Padang City. For common people, the presence of Go-Jek is considered to help their daily life. Starting from the Goride and Go-car facilities which are considered effective in delivering passengers effectively. The reason is caused by the easiness in making an order using the android mobile application. However, it is different from ojek. They considered the presence of this online transportation to threaten their existence. They thought their income had decreased since the existence of this online transportation in Padang. Like the research conducted by Anwar (2017), which revealed that the presence of online transportation made it easier for consumers while for conventional transportation drivers, online transportation was considered as illegal 
transportation and as a usurper of their livelihood.

The climax was that there were two demonstrations (mass strikes) by angkot drivers, on 28 August 2017 and 20 September 2017. One of the coordinators of hundreds of angkot drivers demanded that online transportation be closed, because since this online transportation their income had been down to $75 \%$. (Harianhaluan.com). The Head of the West Sumatra Transportation Office, Mr. Amran explained, the closure of the office was carried out because it was related to the permit for Go-Jek operational activities in Padang. However, Mr. Amran claimed that he was not authorized to close the Go-Jek application, which was a demand point for angkot drivers (national.republika.co.id).

Research by Kunze and Mai (2007); Pi and Sangruang (2011); and Putri, et al. (2013) both produced that time risk and performance risk influenced consumer purchasing decisions while Wulandari and Purnamawati (2013) were only influenced performance risk. Kunze and Mai (2007) about the adoption of music download services showed that performance risk and time risk affected respondents in adopting music downloads. Social risk, psychological risk, physical risk and financial risk did not affect respondents in the adoption of music downloads. Then, Pi and Sangruang (2011) about perceptions of online shopping risk showed that time / convenience risk, physical risk, performance risk, and social risk were the most influential risks when shopping via the internet. Psychological risk and financial risk did not affect respondents shopping through the internet. Then Putri, et al. (2013) about risk perceptions using Garuda Indonesia showed that time risk and performance risk affected respondents in using Garuda Indonesia services. Finally, Wulandari and Purnamawati (2013) about perceptions of the risk of using a motorcycle which showed that only performance risk affected purchasing decisions.

Research by Cunningham et al. (2005) and Hirunyawipada and Paswan (2006) both produced that social risk and physical risk influenced consumer purchasing decisions while Gunawan, et al. (2017) only social risk. Cunningham et al. (2005) conducted research on booking airline tickets over the internet and traditionally. The results showed that performance risk, physical risk, social risk, and financial risk were risky in the customer purchasing process. Psychological risk and time risk did not affect the ticket booking process via the internet. Meanwhile, Hirunyawipada and Paswan (2006) about the adoption of new products showed that social risk and physical risk affected respondents in the adoption of new products. Time risk, performance risk, psychological risk, and financial risk did not influence the adoption of new products. Even financial risk was negative in the adoption of new products. Finally, Gunawan, et al. (2017) about the perception of the risk of buying Airbnb showed that only social risk had an influence on purchasing decisions.

For this reason, the researchers were interested in conducting the research on risk perception, that were RP-Performance and RP-Physical. The purpose of this study was to analyze the RP-Performance and RPPhysical on making decision to use conventional transportation in Padang.

\section{METHODS}

The type of data used in this study are primary data and secondary data. Primary data were obtained through discussions and direct interviews guided by questionnaires. Secondary data were obtained from various literature sources that were considered relevant to the research.

Data collection techniques in this study were carried out using Quota Sampling with direct interview methods to respondents with questionnaire aids. Criteria for prospective 
respondents as an example in this survey were the users of conventional transportation services, that was ojek at least once and were over 17 years old. The operational definitions of each variable used in this study are as follows:

1) Independent variable (X) According to Sarwono (2012), an independent variable is a variable whose variables are measured, manipulated, or chosen by researchers to determine its relationship with an observed symptom. The independent variables in this study are RP-Performance $\left(\mathrm{X}_{1}\right)$ and RP-Physical $\left(\mathrm{X}_{2}\right)$.

2) Dependent variable (Y)

The dependent variable is the variable that gives a reaction or response if it is associated with an independent variable. The dependent variable in this study was the purchasing decision (Y).

The complete data is explained in table 1. below.

Table 1. Definition of Operational Variables

\begin{tabular}{|c|c|c|c|}
\hline \multirow{3}{*}{$\begin{array}{l}\text { Variabel } \\
\mathrm{RP} / \text { Risk } \\
\text { Perception } \\
\text { (X) }\end{array}$} & Sub-Variabel & Operational Definition & Indicator \\
\hline & $\begin{array}{l}\text { Performance Risk } \\
\left(\mathrm{X}_{1}\right)\end{array}$ & $\begin{array}{l}\text { Performance Risk is risks } \\
\text { related to appearance, } \\
\text { friendliness, to driver driving } \\
\text { performance (Gunawan } \text { et al, } \\
\text { 2017; Sumarwan, 2011; Kotler } \\
\text { and Keller, 2009) }\end{array}$ & $\begin{array}{l}\text { 1. Driver's appearance } \\
\text { 2. Driver's hospitality } \\
\text { 3. Driver driving performance } \\
\text { (sources: Kunze dan Mai (2007); Pi dan } \\
\text { Sangruang (2011); Wulandari and } \\
\text { Purnamawati (2013); Putri, et al. } \\
\text { (2013); and Gunawan, et al. } \text { (2017)) }\end{array}$ \\
\hline & $\begin{array}{l}\text { Physical Risk } \\
\left(\mathrm{X}_{2}\right)\end{array}$ & $\begin{array}{l}\text { Physical Risk is a risk related to } \\
\text { the technical standards of } \\
\text { vehicle operations, passenger } \\
\text { safety to the possibility of } \\
\text { "begal" or robbery (Gunawan } \\
\text { et al, 2017; Sumarwan, 2011; } \\
\text { Kotler and Keller, 2009) }\end{array}$ & $\begin{array}{l}\text { 1. Technical standards for the operation } \\
\text { of the vehicle being carried; } \\
\text { 2. passenger safety } \\
\text { 3. The threat of "begal" and robbery } \\
\text { (sources: Cunningham et al. (2005); } \\
\text { Hirunyawipada and Paswan (2006); } \\
\text { Wulandari and Purnamawati (2013); } \\
\text { Putri, et al. (2013); Gunawan, et al. } \\
\text { (2017)) }\end{array}$ \\
\hline $\begin{array}{l}\text { Purchase } \\
\text { Decision } \\
\text { (Y) }\end{array}$ & & $\begin{array}{l}\text { Purchasing decisions are final } \\
\text { consumer purchasing decisions } \\
\text { that include the interest in } \\
\text { repurchasing to recommending } \\
\text { the product / service to others } \\
\text { (Kotler and Keller, 2009) }\end{array}$ & $\begin{array}{l}\text { 1. Repurchase Interest } \\
\text { 2. Recommendation } \\
\text { (sources: Cunningham } \text { et al. (2005); } \\
\text { Hirunyawipada and Paswan (2006); } \\
\text { Kunze and Mai (2007); Pi and } \\
\text { Sangruang (2011); Wulandari and } \\
\text { Purnamawati (2013); Putri, } \text { et al. } \\
\text { (2013); and Gunawan, } \text { et al. (2017)) }\end{array}$ \\
\hline
\end{tabular}

Modes of transportation here included conventional transportation and online transportation. This study only examined the effect of RP-Performance and RP-Physical service users in taking decision, that was ojek. Next in Figure 1 the conceptual framework is presented as follows.

The existence of several problems in electronic payment that cannot be separated in relation to e-commerce become the basis 
of researchers in choosing this research topic. In addition, Indonesia is one of the countries with the largest e-commerce market in Asia, this is also the reasons why researchers choose case studies in Indonesia.

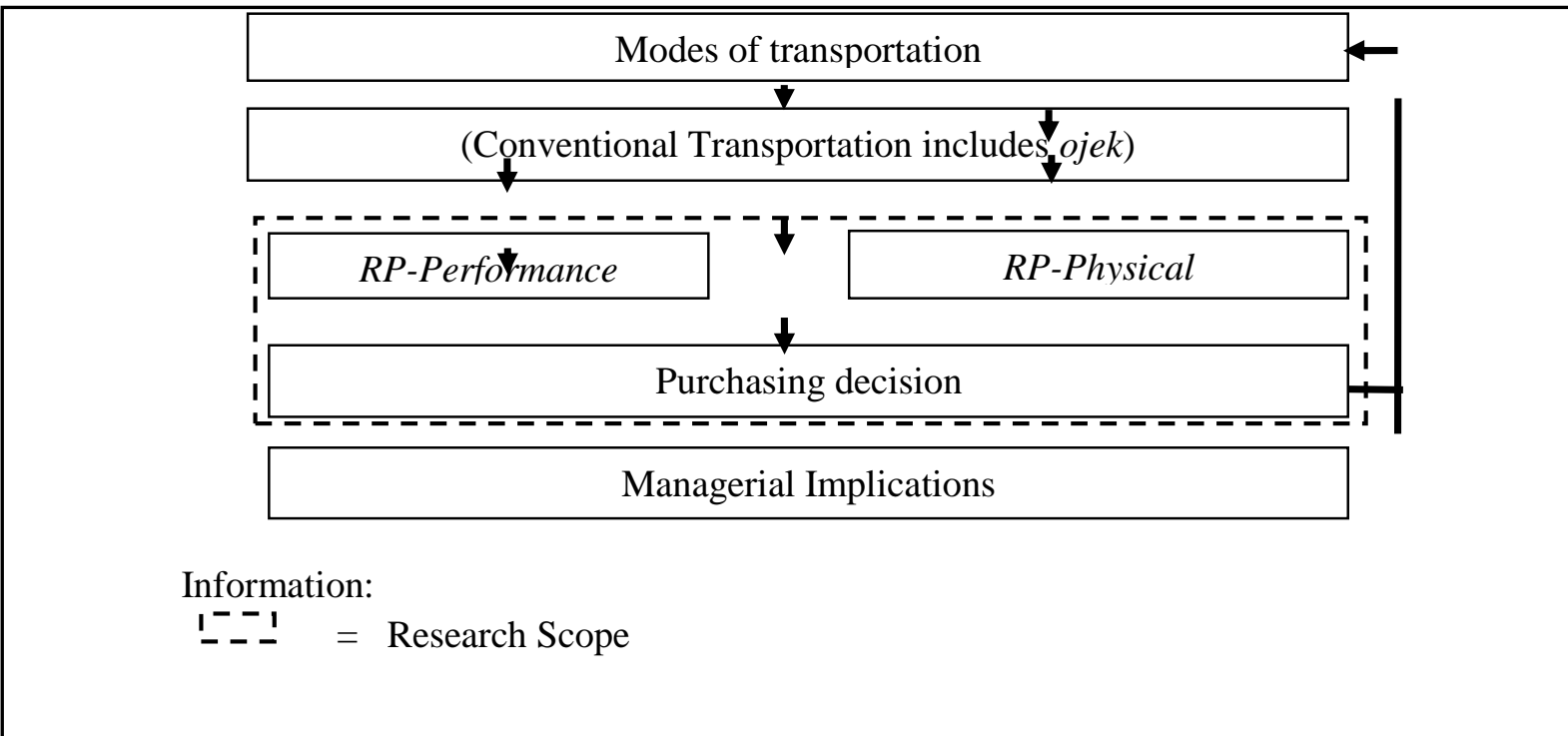

Figure 1. Conceptual Framework

\section{RESULTS AND DISCUSSION \\ Characteristics of Respondents \\ Demographic data includes gender, age, occupation, last education and expenditure on transportation. The complete data is explained in table 2.}

Table 2. Distribution of respondents by demographics

\begin{tabular}{|c|c|c|c|c|}
\hline No. & \multicolumn{2}{|c|}{ Demographics } & \multirow[t]{2}{*}{$\begin{array}{c}\text { Number of respondents } \\
\text { (people) }\end{array}$} & \multirow[t]{2}{*}{$\begin{array}{c}\text { Percentage } \\
(\%)\end{array}$} \\
\hline 1 & Gender & & & \\
\hline & & Male & 282 & 73.4 \\
\hline & & Female & 102 & 26.6 \\
\hline & & Total & 384 & 100 \\
\hline \multirow[t]{7}{*}{2} & Age & & & \\
\hline & & $<25$ years-old & 310 & 80.7 \\
\hline & & $25-35$ years-old & 60 & 15.6 \\
\hline & & $36-45$ years-old & 8 & 2.1 \\
\hline & & $46-55$ years-old & 5 & 1.3 \\
\hline & & $\geq 56$ years-old & 1 & 0.2 \\
\hline & & Total & 384 & 100 \\
\hline \multirow[t]{6}{*}{3} & Occupation & & & \\
\hline & & Student & 34 & 8.9 \\
\hline & & College student & 222 & 57.8 \\
\hline & & Entrepreneur & 21 & 5.5 \\
\hline & & BUMN employees & 20 & 5.2 \\
\hline & & Private employess & 39 & 10.2 \\
\hline
\end{tabular}


Housewife

ASN (Government employees)

Teacher / Lecturer

Army / Police

Others (farmer, laborer, handyman)

Total

4

Last education

SMP (Junior High School)

SMA (Senior High School)

D3(Associate)

S1(Bachelor)

S2 (Magistered)

S3 (Doctor)

Other (dropped out of school)

Total

5 Transportation expenses

$$
\begin{array}{r}
\leq \operatorname{Rp} 50.000 \\
\operatorname{Rp} 50.001-\operatorname{Rp} 75.000 \\
\operatorname{Rp} 75.001-\operatorname{Rp} 100.000 \\
\operatorname{Rp} 100.001-\operatorname{Rp} 125.000 \\
\operatorname{Rp} 125.001-\operatorname{Rp} 150.000 \\
\operatorname{Rp} 150.001-\operatorname{Rp} 175.000 \\
\operatorname{Rp} 175.001-\operatorname{Rp} 200.000 \\
\geq \operatorname{Rp} 200.001
\end{array}
$$

$\begin{array}{rr}17 & 4.4 \\ 4 & 1.0 \\ 10 & 2.6 \\ 3 & 0.8 \\ 14 & 3.6 \\ 384 & 100\end{array}$

$\begin{array}{rr}18 & 4.7 \\ 258 & 67.2 \\ 25 & 6.5 \\ 67 & 17.4 \\ 5 & 1.3 \\ 0 & 0 \\ 11 & 2.9 \\ 384 & 100\end{array}$

$140 \quad 36.5$

$88 \quad 22.9$

$57-14.8$

$30 \quad 7.8$

$20 \quad 5.2$

$10 \quad 2.6$

$18 \quad 4.7$

$21 \quad 5.5$

$384 \quad 100$

\section{Classic assumption test Normality test}

Normality test in the regression model is used to test whether the residual values generated from the regression are normally distributed or not. A good regression model is one that has a normally distributed residual value. In this study, the normality test is as follows :

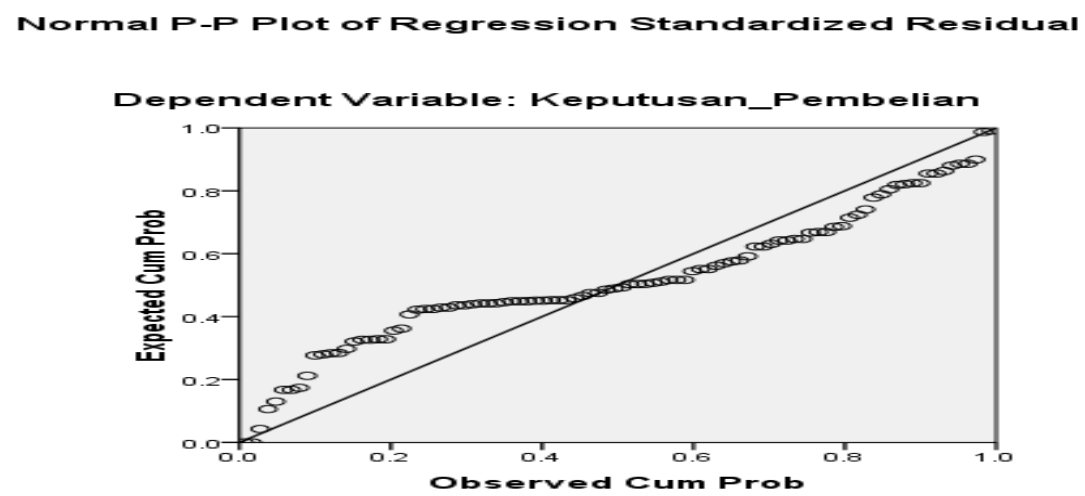

Figure 2. Normality Test

Based on the curve analysis, it can be seen that the data was spread around the diagram and followed the regression model so that it can be concluded that the data processed was normally distributed data so that the normality test is met. 


\section{Multicollinearity Test}

According to Ghozali (2011), multicollinearity test aimed to test whether the regression model found a correlation between independent variables. A good regression model should not become a correlation between independent variables. If there was a correlation between independent variables, then there was a multicollinearity problem in the regression model. To see the presence or absence of multicollinearity in this regression model can be seen from the value of tolerance and Variance Inflation Factor (VIF). If the tolerance value $\geq 0,1$ and VIF value $\leq 10$, then there is no multicollinearity, and vice versa if the tolerance value $\leq 0.1$ and VIF value $\geq 10$ then there is multicollinearity between independent variables in the regression model. For analysis with SPSS we see the outputs in table 3 below:

Table 3. Multicollinearity Test

\begin{tabular}{|c|c|c|c|c|c|c|c|}
\hline \multirow[t]{2}{*}{ Model } & \multicolumn{2}{|c|}{$\begin{array}{l}\text { Unstandardized } \\
\text { Coefficients }\end{array}$} & \multirow{2}{*}{$\begin{array}{c}\text { Standardized } \\
\text { Coefficients } \\
\text { Beta } \\
\end{array}$} & \multirow[t]{2}{*}{$\mathrm{t}$} & \multirow[t]{2}{*}{ Sig. } & \multicolumn{2}{|c|}{$\begin{array}{l}\text { Collinearity } \\
\text { Statistics }\end{array}$} \\
\hline & B & Std Eror & & & & Tolerance & VIF \\
\hline Constant & 5.429 & .177 & & 4.576 & .000 & & \\
\hline Performance & -.131 & .052 & -.193 & -2.491 & .014 & .907 & 1.103 \\
\hline Physical & -.129 & .059 & -.175 & -2.177 & .031 & .844 & 1.185 \\
\hline
\end{tabular}

From the results of the output data it was found that the values of all VIF values $<10$ meant that there was no multicollinearity. And concluded that the classical assumption test was fulfilled.

\section{Heteroscedasticity Test}

According to Ghozali (2011), the heteroscedasticity test aimed to find out whether in the regression model there was an unequal variance from the residuals of one observation to another. If the variance from one observation residual to another observation was fixed, then it was called homokedasticity and if heterokedasticity was different. To detect and analyze the data can be seen in the image "Scatterplot" in the output data as shown below:

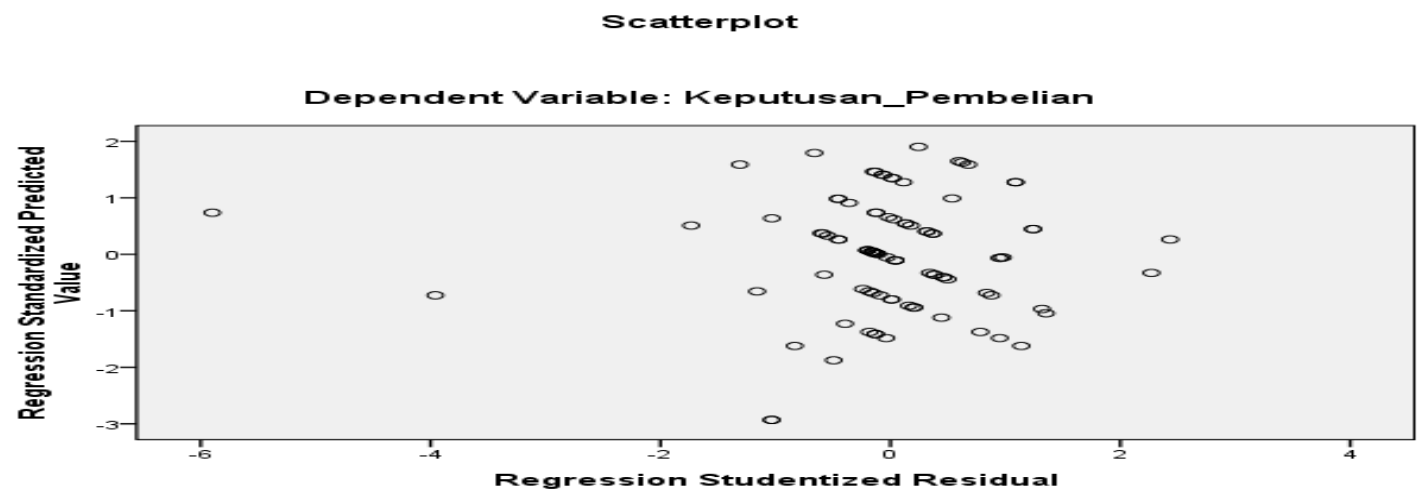

Figure 3. Heteroscedasticity Test 
From Figure 3. above it can be seen that there was no heteroscedasticity because there was no clear pattern and the points spread above and below the number 0 on the $\mathrm{Y}$ axis. So it can be said that the classical assumption test was fulfilled.

\section{Descriptive Analysis}

To find out how respondents' perceptions of performance, physical and purchasing decisions can be described through descriptive analysis. In this research the resulting descriptive analysis is as follows:

Table 4. Descriptive Analysis of Conventional Transportation

\begin{tabular}{|c|c|c|c|}
\hline Statement & Mean & TCR $(\%)$ & Information \\
\hline \multicolumn{4}{|l|}{ PERFORMANCE } \\
\hline $\begin{array}{l}\text { I still choose conventional transportation (ojek) even } \\
\text { though the drivers look sloppy }\end{array}$ & 2.34 & 60.89 & Enough \\
\hline $\begin{array}{l}\text { I still choose conventional transportation (ojek) even } \\
\text { though the driver is not friendly }\end{array}$ & 2.06 & 53.71 & Enough \\
\hline $\begin{array}{l}\text { I still choose conventional transportation (ojek) even } \\
\text { though the driver is reckless when driving } \\
\text { PHYSICAL }\end{array}$ & 1.71 & 44.62 & Enough \\
\hline $\begin{array}{l}\text { I still choose conventional transportation (ojek) even } \\
\text { though the vehicle used does not meet the standards }\end{array}$ & 1.91 & 49.70 & Enough \\
\hline $\begin{array}{l}\text { I still choose conventional transportation (ojek) even } \\
\text { though my safety is threatened }\end{array}$ & 1.78 & 46.45 & Enough \\
\hline $\begin{array}{l}\text { I still choose conventional transportation (ojek) } \\
\text { despite the threat of "begal" and robbery }\end{array}$ & 1.76 & 45.84 & Enough \\
\hline PURCHASING DECISION & & & \\
\hline $\begin{array}{l}\text { I will continue to use conventional transportation } \\
\text { (ojek) again }\end{array}$ & 3.22 & 83.75 & Very good \\
\hline $\begin{array}{l}\text { I would recommend conventional transportation } \\
\text { (ojek) to others }\end{array}$ & 3.12 & 81.24 & Very good \\
\hline
\end{tabular}

In this study it was found that the Performance variable of the 3 (three) statements answered sufficiently, with the highest value of the statement "I still choose conventional transportation (ojek) even though the drivers looked sloppy" with a score of $60.89 \%$ respondent achievements. While the lowest statement was the statement "I still choose conventional transportation (ojek) even though the driver was reckless in driving" with the value of the respondent's achievement level of $44.62 \%$.

In the Physical variable of the 3 (three) statements answered sufficiently, with the highest value that was the statement "I still choose conventional transportation (ojek) even though the vehicle used did not meet the standards" with the respondent's achievement level value of $49.70 \%$. While the lowest statement was the statement "I still choose conventional transportation (ojek) despite the threat of "begal" and robbery" with a value of $45.84 \%$ level of respondents' achievements.

On the Purchase Decision variable of the 2 (two) statements answered very well that was the statement "I will continue to use conventional transportation (ojek) again" with the value of the level of achievement of respondents $83.75 \%$. While the lowest statement was the statement "I would recommend conventional transportation (ojek) to other people" with a score of $81.24 \%$ achievement rate.

\section{Multiple Linear Regression Analysis}

Regression analysis is used to find out how much influence the independent variable has on the dependent variable. In this research, multiple linear regression analysis 
is as follows:From the results of the output data it was found that the values of all VIF values $<10$ meant that there was no multicollinearity. And concluded that the classical assumption test was fulfilled.

Table 5. Conventional Linear Regression Analysis

\begin{tabular}{|c|c|c|c|c|c|c|c|}
\hline \multirow[t]{2}{*}{ Model } & \multicolumn{2}{|c|}{$\begin{array}{c}\text { Unstandardized } \\
\text { Coefficients }\end{array}$} & \multirow{2}{*}{$\begin{array}{c}\text { Standardized } \\
\text { Coefficients } \\
\text { Beta } \\
\end{array}$} & \multirow[t]{2}{*}{$\mathrm{T}$} & \multirow[t]{2}{*}{ Sig. } & \multicolumn{2}{|c|}{$\begin{array}{c}\text { Collinearity } \\
\text { Statistics }\end{array}$} \\
\hline & B & Std Eror & & & & Tolerance & VIF \\
\hline Constant & 5.429 & .177 & & 4.576 & .000 & & \\
\hline Performance & -.131 & .052 & -.193 & -2.491 & .014 & .907 & 1.103 \\
\hline Physical & -.129 & .059 & -.175 & -2.177 & .031 & .844 & 1.185 \\
\hline
\end{tabular}

Based on Table 5, obtained the multiple linear regression analysis as follows :

$$
\mathrm{Y}=5.429-0.131 \mathrm{X}_{1}-0.129 \mathrm{X}_{2}
$$

From this equation it can be explained that:

1) The constant was positive at 5.429. This showed that if there were no physical and performance variables, the decision to use ojek services is fixed at 5.429.

2) Performance coefficient $\left(X_{1}\right)$ is negative, that is 0.131 and the significance value is $0.014<0.05$. This showed that if the performance increased by one-unit, the decision to use ojek (Y) services would decrease by 0.131 or $13.1 \%$ with the assumption that physical remained.
3) Physical coefficient $\left(X_{2}\right)$ was negative, that was 0.129 and the significance value was 0.031 $<0.05$. This showed that if the physical increased by one-unit, the decision to use ojek (Y) services would decrease by 0.129 or $12.9 \%$ with the assumption of fixed performance.

\section{Hypothesis test}

\section{Partial Test (t test)}

According to Sugiyono (2014), the $t$ test was used to find out each contribution of the independent variable partially to the dependent variable, using the test of each independent variable regression coefficient whether it had a significant effect on the dependent variable or not In this study the $t$ test is as follows:

Table 6. Conventional Transportation t Tests

\begin{tabular}{|c|c|c|c|c|c|c|c|}
\hline \multirow[t]{2}{*}{ Model } & \multicolumn{2}{|c|}{$\begin{array}{c}\text { Unstandardized } \\
\text { Coefficients }\end{array}$} & \multirow{2}{*}{$\begin{array}{c}\text { Standardized } \\
\text { Coefficients } \\
\text { Beta } \\
\end{array}$} & \multirow[t]{2}{*}{$\mathrm{T}$} & \multirow[t]{2}{*}{ Sig. } & \multicolumn{2}{|c|}{$\begin{array}{c}\text { Collinearity } \\
\text { Statistics }\end{array}$} \\
\hline & B & Std Eror & & & & Tolerance & VIF \\
\hline Constant & 5.429 & .177 & & 4.576 & .000 & & \\
\hline Performance & -.131 & .052 & -.193 & -2.491 & .014 & 907 & 1.103 \\
\hline Physical & -.129 & .059 & -.175 & -2.177 & .031 & .844 & 1.185 \\
\hline
\end{tabular}

Based on Table 6., the $\mathrm{t}$ test can be interpreted as follows :

1. The effect of RP-Performance on purchasing decisions hypothesis testing results RP-Performance $\left(\mathrm{X}_{1}\right)$ partially showed $t$ count of -2.491 smaller than $t$ table of -1.978 with a significance of 0.014 smaller than 0.05 which meant that the hypothesis in this study rejected Ho and accept Ha. Then it can be concluded that the $\mathrm{H} 1$ hypothesis "RP-Performance $\left(\mathrm{X}_{1}\right)$ had a significant negative effect on purchasing decisions".

2. The effect of RP-Physical on purchasing decisions hypothesis testing results RPPhysical $\left(\mathrm{X}_{2}\right)$ partially showed t-count of 2.177 was smaller than $t$ table of -1.978 with a significance of 0.031 less than 0.05 
which meant that the hypothesis in this study rejected Ho and accept $\mathrm{Ha}$. Then it could be concluded that the $\mathrm{H} 2$ hypothesis "RP-Physical $\left(\mathrm{X}_{2}\right)$ had a significant negative effect on purchasing decisions".

\section{Simultaneous Test (F Test)}

Sugiyono (2014), stated that the F test was used to determine whether the simultaneous coefficient of the independent variable had a real effect or not on the dependent variable. In this study the F test is as follows:

Table 7. Conventional Transportation F Test

\begin{tabular}{|c|c|c|c|c|c|}
\hline Model & Sum of Squares & Df & Mean Squares & F. & Sig \\
\hline Regression & 332.441 & 9 & 10.088 & 38.403 & .000 \\
\hline Residual & 322.207 & 374 & .085 & & \\
\hline Total & 682.648 & 383 & & & \\
\hline
\end{tabular}

The results of testing the $R P$ Performance and RP-Physical hypotheses on purchasing decisions showed a calculated $\mathrm{F}$ value of 38,403 with a significance level of 0,000 . The significance level wass less than 0.05 , which meant that the hypothesis in this study rejected Ho and accepted $\mathrm{Ha}$. Thus it can mean that the hypothesis "RP-Performance and $R P$-Physical had a significant influence on purchasing decisions".

\section{Coefficient of Determination $\left(\mathbf{R}^{\mathbf{2}}\right)$}

According to Ghozali (2011), the coefficient of determination $\left(\mathrm{R}^{2}\right)$ basically measured how far the model's ability to explain variations in the dependent variable. The coefficient of determination was between zero and one. A small $\mathrm{R}^{2}$ value meant that the ability of the independent variables to explain the dependent variable was very limited. A value closed to one meant that the independent variables provided almost all the information needed to predict the variation of the dependent variable. In this study the coefficient of determination of the $R P$ Performance and RP-Physical tests on purchasing decisions is as follows:

Table 8. Conventional Transportation Coefficient Test $\left(\mathbf{R}^{2}\right)$

\begin{tabular}{|c|c|c|c|c|c|c|c|c|c|c|}
\hline \multirow[t]{2}{*}{ Model } & \multirow[t]{2}{*}{$\mathrm{R}$} & \multirow[t]{2}{*}{ R Square } & \multirow{2}{*}{$\begin{array}{c}\text { Adjusted R } \\
\text { Square }\end{array}$} & \multirow{2}{*}{$\begin{array}{l}\text { Std. Error of } \\
\text { the Estimate }\end{array}$} & \multicolumn{5}{|c|}{ Change Statistics } & \multirow{2}{*}{$\begin{array}{l}\text { Durbin } \\
\text { Watson }\end{array}$} \\
\hline & & & & & $\begin{array}{l}\text { R Square } \\
\text { Change }\end{array}$ & F Change & df1 & df2 & $\begin{array}{c}\text { Sig. F } \\
\text { Change }\end{array}$ & \\
\hline 1 & $.538 a$ & .290 & .257 & .23800 & .290 & 8.903 & 9 & 374 & .000 & 1.652 \\
\hline
\end{tabular}

a. Predictors: (Constant), Performance, Physical

b. Dependent Variable: Purchasing decision

From Table 8. it showed that the influence of RP-Performance and RP-Physical on purchasing decisions was 0.257 or $25.7 \%$ while the remaining $74.3 \%$ was influenced by other variables not examined in this study.

From the results that have been processed using SPSS, it can be explained the use of conventional transportation as follows:

\section{The effect of RP-Performance on} purchasing decisions based on the results of hypothesis testing
RP-Performance variable shows the t value of -2.491 is smaller than t table of -1.978 and the significance level of 0.014 is smaller than 0.05 . Then it can be concluded that "RP-Performance $\left(\mathrm{X}_{1}\right)$ has a negative and significant effect on purchasing decisions". This means that consumers who have consumed products or services that have been given tend to choose or decide on a product or service depending on performance so that it will have a negative impact on purchasing decisions. The results 
of this study contradict the research conducted by Kunze and Mai (2007); Pi and Sangruang (2011); Wulandari and Purnamawati (2013); and Putri, et al. (2013) where the result of regression coefficient is positive. However, contrary to research conducted by Gunawan, et al. (2017).

2. The effect of RP-Physical on purchasing decisions based on the results of hypothesis testing

The variable RP-Physical $\left(\mathrm{X}_{2}\right)$ shows the $\mathrm{t}$ value of -2.177 is smaller than $t$ table of 1.978 and the significance level of 0.031 is smaller than 0.05 . Then it can be concluded that "RP-Physical $\left(\mathrm{X}_{2}\right)$ has a negative and significant effect on purchasing decisions". This means that consumers who have consumed products or services that have been given tend to choose or decide on a product or service depending on the physical vehicle and the existing environmental situation so that it will have a negative impact on purchasing decisions. The results of this study contradict the research conducted by Cunningham et al. (2005); Hirunyawipada and Paswan (2006); Wulandari and Purnamawati (2013); and Putri, et al. (2013) where the result of regression coefficient is positive. However, contrary to research conducted by Gunawan, et al. (2017).

\section{Overall Effect of Risk Perception (RP) on purchasing decisions}

The results of the F test (simultaneously) RP-Performance and RP-Physical on purchasing decisions amounted to 0.257 or $25.7 \%$. This shows that RP-Performance and $R P$-Physical are able to explain their effect on purchasing decisions by $25.7 \%$, while the remaining $74.3 \%$ is influenced by other factors.

\section{CONCLUSION}

The first hypothesis was accepted, where the results of the study indicate that $R P$ Performance partially has a negative and significant effect on purchasing decisions. So it can be concluded that consumers who have consumed products or services that have been given tend to choose or decide on a product or service depending on performance so that it will have a negative impact on purchasing decisions.

The second hypothesis was accepted, where the results of the study show that $R P$ Physical partially has a negative and significant effect on purchasing decisions. So it can be concluded that consumers who have consumed products or services that have been given tend to choose or decide on a product or service depending on the physical vehicle and the existing environmental situation that will have a negative impact on purchasing decisions.

The third hypothesis was accepted, where the results of the study show that $R P$ Performance and RP-Physical can simultaneously explain their effect on purchasing decisions by $25.7 \%$. So it can be concluded that the RP-Performance and RPPhysical are able to explain its effect on purchasing decisions by $25.7 \%$.

\section{RECOMMENDATION}

Each driver is more concerned with performance risks and the physical risks of drivers and vehicles used in serving consumers. These conventional "ojek" drivers usually stand alone (not partners) and no one controls them routinely. Controling of driver and vehicle performance should come from the driver himself. This needs to be done if conventional transportation does not want to be abandoned by consumers and switch to online transportation.

\section{ACKNOWLEDGMENTS}

The authors would like to thank to the Ministry of Research, Technology, and Higher Education Directorate General for Strengthening Research and Development for the funding of Beginner Lecturer Research 
(PDP) 2019. Acknowledgments also the authors convey to the institution, fellow lecturers, and students of the University of Dharma Andalas (Unidha) who have provided support to the author so that this research can be completed and it provide benefits for the development of knowledge, especially marketing management, specifically the behavior of consumers of online transportation services users for the interests of institutions and writers in improving performance as a lecturer.

\section{REFERENCE}

Anwar A. (2017). Online vs Conventional: Excellence and Conflict between Modes of Transportation in Makassar. Jurnal Etnografi Indonesia.Vol. 2.Edisi ke-2.

Cunningham LF, James HG, Michael DH, Clifford EY. (2005). Perceived Risk and the Consumer Buying Process: Internet Airline Reservations. Service Management 16:357-373.

Ghozali, I. (2011). Aplikasi Analisis Multivariate dengan Program IBM SPSS 19.Edisi ke-5.Semarang: Universitas Diponegoro.

Gunawan, Melissa, Evelien Alim Sompie, Fransisca Andreani. (2017). Analysis of the Influence of Risk Perceptions on Purchasing Decisions at AIRBNB. Journal of Hospitality Management Program Management Study Program Faculty of Economics Petra Christian University.

Harianhaluan.com [accessed on July 28, 2019 at 22.52]

Hirunyawipada T, Paswan AK. (2006). Consumer Innovativeness \& Perceived Risk: Implications for High
Technology Product Adoption. Marketing and Logistic 23(4):182-198.

Kotler P, Kevin LK. (2009). Marketing Management. Edisi ke-13. Jilid I. Jakarta: Erlangga. Translation from: Bob Sabran

Kunze O, Mai L. (2007). Consumer Adoption of Online Music Services: The Influence of Perceived Risk and Riskrelief Strategies. Retail and Distribution Management 35(11):862877.

Nasional.republika.co.id [accessed on Agustus 20,2018 at 10.25]

Pi SM, Sangruang J. (2011). The Perceived Risks of Online Shopping in Taiwan. Social Behavior and Personality 39(2):275.

Putri, SL, Lilik NY, Febriantina D. (2012). Analysis of Consumer Attitudes Towards Airlines and the Influence of Risk Perception on Decisions Using Indonesian Garuda Services [thesis]. Bogor: Sekolah Program Pascasarjana, InstitutPertanian Bogor.

Putri, SL, Lilik NY, Febriantina D. (2013). Analysis of Consumer Attitudes Towards Airlines and the Influence of Risk Perception on Decisions Using Indonesian Garuda Services. Ekonomi and Bisnis Dharma Andalas. Vol. 14 No.1 49-62.

Sarwono J. (2012). Thesis Research Methods A Quantitative Approach Using the SPSS Prosedure. 1st Ed. Jakarta: Elex Media Komputindo.

Sugiyono. (2014). Business Research Method. Bandung: Alfabeta.

Sumarwan U, Ahmad J, Asep M, Bagio NK, Ponti KM, Wahyu N. (2011). 
Marketing and Consumer Research (Research and Study Guidelines: Satisfactions, Buying Behavior, Lifestyle, Loyalty, and Risk Perception). Bogor: IPB Press.

Wulandari, Retno, dan Purnamawati, A. (2013). Effects of Risk: Psychological, Financial, Social, Performance, Physical on Overall Risk Perception in Motorcycle Consumers. Journal of Efektif Bisnis and Ekonomi. Vol. 4 No.

2. Desember 2013, page: 149-164. 